\title{
Theoretical and Methodological Aspects of Using Dialogue for the Purpose of Organizing Productive Interaction of Subjects of the Educational Process
}

\author{
Vanda Vyshkivska \\ Ph.D., Associate Professor \\ Dragomanov National Pedagogical University (Ukraine Kyiv) \\ Oleksandra Shykyrynska \\ Ph.D., Associate Professor \\ Vinnytsia Mykhailo Kotsiubynskyi State Pedagogical University (Ukraine \\ Vinnytsia) \\ Olena Malinka \\ Ph.D., Senior Lecturer \\ Vinnytsia Mykhailo Kotsiubynskyi State Pedagogical University (Ukraine \\ Vinnytsia) \\ Inna Lobachuk \\ Ph.D., Senior Lecturer \\ Vinnytsia Mykhailo Kotsiubynskyi State Pedagogical University (Ukraine \\ Vinnytsia)
}

\begin{abstract}
The article in the historical and philosophical, psychological and pedagogical aspects considers the current problem of improving pedagogical education - the use of dialogue in the implementation of effective interaction of the subjects of the educational process. It is emphasized that the modern pedagogical system is faced with objective processes of democratization in society, with the requirements of cultural development in terms of the scientific and technological progress, and is characterized by changing disciplinary and compulsory regulatory dominant of education to the dominant of cultural activity and creativity. Dialogue is analyzed as a form and method of organizing of the educational process that is based on the values of content and values of goal which are manifested in the problematic character, perception and mutual understanding at the interpersonal level. It is noted that the joint participation of the subjects of dialogue reveals its humanistic essence and gives multicolor, emotionality, spirituality to the relationship, gives the joy of their discovery of each other.

Emphasis is placed on the psychological and pedagogical essence of discussion (a kind of dialogue that takes place in a mode of competent equality and involves the clash of the participants' opinions in the course of strictly regulated negotiation of the problem) as the most cognitively effective form of dialogue.

Key words: dialogue, educational dialogue, pedagogical interaction, participants in the educational process, subjects of the educational process, discussion
\end{abstract}


Актуальність дослідження і постановка проблеми. Сучасний період розвитку освіти характеризується докорінним перетворенням самої піi парадигми - від авторитарної до гуманістичної, яка ставить у центр уваги особистість учня, активно включеного в процес вибору змісту, форми і методів свого навчання.

Згідно принципів гуманістичної психології (А. Маслоу, К. Роджерс та ін.) такий новий підхід до навчання передбачає, що: - сучасна освіта виходить із загальнолюдських цінностей та 3 їх узгодження 3 конкретними цінностями різних етнокультурних спільнот; - метою освіти визначено процес самореалізації особистості, для якої характерною $є$ гуманістична спрямованість іiі цінностей; - розвиток особистості відбувається цілісно, в єдності розуму і почуттів, душі і тіла; - усі права людини, в тому числі і її право на вільний вибір змісту, форм освіти, захищені; - освіта здійснюється за допомогою власної діяльності учня;

- групова робота в школі поєднується з індивідуальною роботою, причому особлива увага приділяється розвитку індивідуального стилю діяльності особистості;

- освіта як діяльність особистості грунтується на внутрішній мотивації учня, а також на повноцінному спілкуванні вчителя і учнів, причому участь школярів у рівноправному діалозі поважається і заохочується;

- найуспішніше навчання здійснюється в обстановці турботи, уваги, співпраці, а не формального керівництва [7].

Відтак, важливим завданням викладача $\epsilon$ включення учня в якості активного учасника в групову взаємодію на основі творчого діалогу в системі "вчитель - учень", "учні - учні". По суті, мова йде про проблемно-діалогічний підхід до навчання.

Мета статті - проаналізувати феномен діалогу, його внутрішню сутність і розмаїття зовнішніх проявів як одну з умов реалізації проблемно-методологічної стратегії діяльності учня (студента) за умови його активної участі у процесі навчання, як форму і метод організації ефективної взаємодії суб'єктів освітнього процесу.

Виклад основного матеріалу. У тлумачних словниках кінця XX ст. термін "діалог" визначався досить просто. Так, в Енциклопедичному словнику (1985р.) діалог характеризувався як одна 3 форм усного мовлення (поряд 3 монологом), тобто як розмова двох або кількох осіб. Малися на увазі життєвий і діловий діалог, а також його відображення в художній літературі, а іноді - у філософській (наприклад, діалоги 
Платона). У психологічному словнику 1985 р. (під ред. А. В. Петровського та М. Г. Ярошевського) діалог визначався як почерговий обмін репліками двох і більше людей (в широкому сенсі реплікою вважається не тільки мовне висловлювання, але i відповідь у вигляді жесту і навіть мовчання).

Однак останнім часом поняття діалогу стало набувати все більш широких концептуальних меж. Дослідження, проведені в галузі філософії, культурології, психології, педагогіки та інших наук (М. М. Бахтін, В. С. Біблер, М. Бубер, М. С. Каган, І.А.Колеснікова та ін.), призвели до розуміння того, що діалогічність $є$ центральною характеристикою гуманітарно-орієнтованої взаємодії між людьми (індивідами, групами, спільнотами), вона - універсальний спосіб існування культури і людини в культурі, внутрішній механізм розвитку людського мислення. Зокрема, у концепції В.С. Біблера діалог проникає в саме серце сучасної шкільної освіти, яка визначається як «школа діалогу культур» [2].

Предметом грунтовного наукового аналізу діалог став зовсім нещодавно, що можна обгрунтувати усвідомленням того факту, що подолання глобальної кризи людства в навчанні, економіці, політиці і т.ін. можливе не шляхом конфронтації, а шляхом діалогу, зусиллями взаємного розуміння і довіри між викладачем і студентом, людьми, народами, країнами, конфесіями, партіями.

На Міжнародній конференції в 1992 році відомий фізик Д. Бом розкрив значення діалогу в наш час. Він стверджує, що подолання розбіжностей можливо тільки в разі «поділу сенсу», що сприяє створенню такої культури, яка могла б стати планетарною. Для цього необхідно створити умови для початку діалогу. Люди різних субкультур могли б зібратися і почати пошук спільних смислів, можливо, навіть нових, які все могли б прийняти. При цьому діалог слід почати з тими, хто є достатньо відкритим, - не можна говорити 3 тими, хто цього не хоче. А також науковець наголосив, що нам потрібен діалог у прямому значенні цього слова, згідно з яким “сенс тече крізь і серед людей на відміну від обміну, де кожен намагається виграти, утвердивши свій погляд”. А отже, діалог означає створення чогось нового, коли виграють усі [3].

В освіті ж інтерес до діалогічної взаємодії став помітно зростати в міру переходу школи від колишньої авторитарної парадигми до парадигми гуманістичної, в 
рамках якої міжсуб'єктний діалог створює найбільш сприятливі умови для вільного самовираження учнів.

Розглянемо це питання більш детально. Як відомо, формування діалогічної природи мислення і мовлення потребує реалізації двох взаємопов'язаних процесів. Дитина опановує своїми першими уявленнями спочатку в зовнішньому розгорнутому спілкуванні з дорослими, яке поступово переходить у спілкування внутрішнє, в розмову людини з самою собою. Це процес інтеріоризації, в результаті якого діалог стає опорою мислення у внутрішньому плані. Мислення, з певної точки зору, і $є$ не що інше, як внутрішній діалог.

Необхідність звернення до психологічного аспекту діалогу обумовлена й тим, що в сфері педагогічної праці процес міжособистісного спілкування $є$ основним засобом, за допомогою якого реалізуються завдання навчання.

К.А. Альбуханова-Славська, розглядаючи діалог як особливий спосіб мислення, вважає, що він розкриває суть діалектичного мислення: за припущенням слідує заперечення, припущення включає безліч альтернатив, кожна з яких зважується, обдумується i перевіряється. А також учена зазначає, що діалог становить вирішальний інтелектуальний центр саморегуляції особистості, саме в діалозі людина відображає ставлення до подій [1].

А.А. Бодальов і Г.А. Ковальов також акцентують увагу на факті діалогічності змісту психічної організації людини і обгрунтовують стратегію взаємодії, яка $\epsilon$ найбільш доцільною для реалізації інтерсуб'єктного підходу. Також зауважують, що психологічною умовою реалізації такої стратегії визначається діалог [8].

У цілому, психологи пропонують кілька площин інтерпретації цього поняття:

- первинна, родова форма людського спілкування, яка визначає здоровий психічний розвиток особистості;

- провідна детермінанта цього розвитку, що забезпечує функціонування механізму інтеріоризації;

- принцип і метод вивчення людини;

- вищий рівень організації відносин між людьми;

- творчий процес. 
Таким чином, з точки зору психології, діалог є складним, поліфункціональним, соціально-психофізіологічним феноменом, що пронизує весь життєвий простір людини як на рівні психофізичних, так і на рівні соціальних відносин.

Будь-який діалог спрямований на вирішення певної проблеми, причому проблеми досить складної, неоднозначної, багатогранної. Діалог - це первинна і найбільш фундаментальна форма в генезі міжособистісного спілкування, в процесі якого людина вступає в безпосередній контакт з іншими людьми, обмінюється 3 ними думками з того чи іншого питання, намагається з'ясувати те, що їй незрозуміло, підтверджує або спростовує наявні у неї точки зору.

I.А. Кузьмичова також зауважує, що діалог «спирається на особисту активність людини в комунікативних процесах, яка забезпечується тим, що вона включається в процес вирішення проблем, зміст яких для неї є справді глибоко особистісним» [8].

Природно, що основою діалогу є комунікація як умова обміну інформацією, яка пов'язана не стільки з наявністю питань, відповідей на питання, реплік, скільки 3 певним рівнем взаєморозуміння і цілеспрямованого бажання взаємодіяти. Саме діалогкомунікація - це вміння інформувати і отримувати інформацію, бажання розуміти i бути зрозумілим, прагнення бути відкритим і бути успішним. Кожен учасник діалогу представлений як самостійна, активна, вільна особистість, як партнер суб'єктсуб'єктної взаємодії. Діалог передбачає наявність несуміжних смислових позицій, відмінність точок зору. При цьому аргументація кожного з учасників грунтується на комунікативно-ціннісному аспекті взаємодії як основі вираження ставлення до подій.

I.I. Риданова вважає, що навчальний діалог в освітньому процесі грає специфічну роль і «є механізмом реалізації проблемного навчання, допомагає уникнути формального засвоєння знань» [9].

Специфічними є також форми і види навчального діалогу. У сучасній педагогічній науці розглядаються різні форми діалогу, однією з яких є лекція, де діалог лектора і слухачів - організоване і соціально орієнтоване спілкування для формування потрібних уявлень, думок, переконань 3 деяких питань, у той час як лекція в традиційному уявленні за своєю структурою і функціями близька до доповіді, звіту, повідомленням і т.ін. 
Широкого використовується також діалог у формі опитування. До нього належать: соціологічне опитування громадської думки, усне опитування студентів на семінарах, учнів на уроках і т.ін. Дана форма діалогу дає можливість отримати інформацію про об'єктивні чи суб'єктивні факти зі слів опитуваного.

У виразній формі діалогічність проявляється в бесіді, суперечці, дискусії, диспуті, дебатах, полеміці. У бесіді ऑiі учасники при однаковому погляді на обговорюваний предмет, обмінюючись думками в діалозі, розвивають і доповнюють своє розуміння цього предмета.

Найбільш поширеною і «сильною» в пізнавальному контексті є така форма діалогу, як дискусія.

Дискусія - це чітке зіставлення точок зору щодо актуальних питань 3 метою знаходження шляхів їх вирішення та встановлення загальної згоди.

М.М. Діаніна вважає, що відмінною рисою дискусії $є$ те, що вона «являє собою спільну пізнавальну діяльність, яка виникає за умови наявності об'єктивного предметно-логічного конфлікту, що характеризується розбіжністю поглядів учасників на предмет обговорення». При цьому під конфліктом автор розуміє «не конфлікт особистостей, що виражається в їхній конфліктній поведінці, а конфлікт ідей». Інакше кажучи, суттєвою ознакою дискусії є зіткнення в ній протилежних думок і полемічний характер рішення висунутої проблеми. Без зіткнення думок дискусія просто не виникає.

Культура дискусії передбачає дотримання кожним учасником певних норм і правил щодо яких має бути встановлено загальну згоду. Зокрема:

- вільний обмін думками: кожен індивід є рівноправним учасником спільного рішення проблеми; він має право на висловлювання власних думок про можливі варіанти вирішення; висування гіпотез та ідей; в процесі програвання варіантів вирішення кожному надається право на помилки, а на перших етапах пошуку зазвичай вводиться заборона на критику;

- повага до думки кожного учасника: думка, висловлена учасником, не може залишитися поза увагою; вона повинна бути "почута" і використана в ході обговорень (а в іншому випадку виникає "діалог глухих"); важливо зрозуміти його, знайти плюси і 
мінуси, прийняти хоча б в якості тимчасового припущення i "програти" можливі наслідки;

- терпимість до критики: кожен учасник групового рішення уникає спокуси вважати, що істинним є тільки його власне розуміння справи; важливо сприймати критичні висловлювання як більш точні варіанти вирішення; важливо заохочувати критику щодо своєї точки зору, а також відкрито визнавати вади у власній думці (природно, мова йде про критику по суті справи).

У нашому розумінні діалог виступає і одним із основних принципів викладання, який означає, що діалог поширюється на більшість конкретних навчальних дій і застосовується всіма учасниками навчання. Навчальні дії можуть бути спрямовані як на підготовку діалогу в аудиторії, так і проведення власне діалогу і використання його в різних вправах. У діяльність, спрямовану на підготовку діалогу в аудиторії, ми включаємо: діагностику студентів в групі; накопичення фактичних матеріалів; пошук протиріч в дійсності, думках, ідеях; формулювання думок, ідей, теорій; усвідомлення існування індивідуального досвіду учнів і вчителя; актуалізацію знань і використання знань і досвіду, отриманих 3 інших областей; активізацію позашкільних знань; мотивацію і підготовку до діалогу в різних формах (провокаційні питання або завдання, проблемні питання); вибір відповідних методів навчання, які дозволяють вступати в діалог і т. ін.

Висновки. Таким чином, використання діалогу з метою організації ефективної педагогічної взаємодії є досить продуктивним, оскільки він сприяє високому ступеню мотивації, максимальної індивідуалізації навчання та передбачає широкі можливості для творчості, самореалізації суб'єктів освітнього процесу.

Перспективи подальших досліджень пов’язані з вивченням особливостей застосування діалогу з учнями різних вікових груп та різних напрямів навчання.

\section{References}

1. Abulkhanova-Slavskaia K.A. Lychnostnbii aspekt problembl obshchenyia [The personal aspect of the communication problem]/ K.A. Abulkhano-va-Slavskaia // Problema obshchenyia $v$ psykholohyy [The problem of communication in psychology]/ ed. B.F. Lomova. M.: Nauka, 1981. 335 s. 
2. Bybler B.C. Dyaloh kultur (fylosofyia, psykholohyia, pedahohyka) [Dialogue of cultures (philosophy, psychology, pedagogy)] / B.C. Bybler // Pervoe sentiabria, 1998. S. 36.

3. Bom D. Nauka y dukhovnost, neobkhodymost yzmenenyia $v$ kulture [Science and spirituality, the need for change in culture]/ D. Bom // Chelovek. 1993. № 1. S. 7-17.

4. Buber M. Ya y ty [Me and you]/ M. Buber. M.: Vysshaia shkola, 1993. $198 \mathrm{~s}$.

5. Vyshkivska V.B. Subiektnist studentiv u navchalnomu protsesi-neobkhidna umova formuvannia profesiinoi kompetentnosti. [Subjectivity of students in the educational process is a necessary condition for the formation of professional competence] Naukovyi chasopys NPU imeni M.P.Drahomanova. [Scientific journal of NPU named after M.P.Dragomanov] 2008. Vyp.8 (18). C. $2-4$.

6. Vyshkivska V., Shykyrynska O. Orhanizatsiia protsesu navchannia v novii ukrainskii shkoli: teoretyko-praktychnyi aspekt [Organization of the learning process in the new Ukrainian school: theoretical and practical aspect] // Molod i rynok, 2019. № 11 (178) . S. $115-119$

7. Kuliutkyn Yu.N., Bezdukhov V.P. Tsennostnble oryentyrbl y kohnytyvnble strukturb $v$ deiatelnosty uchytelia. [Values and cognitive structures in the teacher's activity.] Samara: SamHPU, 2002. $400 \mathrm{~s}$.

8. Obshchenye $y$ dyaloh $v$ praktyke obuchenyia y vospytanyia y psykholohycheskoi konsultatsyy: [Communication and dialogue in the practice of teaching and education and psychological counseling:] sb. nauch. tr. M.: APN SSSR, 1987. $164 \mathrm{~s}$.

9. Rydanova Y.Y. Osnovy pedahohyky obshchenyia [Fundamentals of communication pedagogy] / Y.Y. Rydanova. Mynsk: Belarusskaia nauka, 1998. 320 s.

10. O. V. Shykyrynska, V. B. Vyshkivska. Google-clasroom yak zasib formuvannia IKTkompetentnosti maibutnoho vchytelia pochatkovoi shkoly [Google-clasroom as a means of forming ICT competence of the future primary school teacher] // Naukovi zapysky Vinnytskoho derzhavnoho pedahohichnoho universytetu imeni Mykhaila Kotsiubynskoho. [Scientific notes of Vinnytsia State Pedagogical University named after Mykhailo Kotsyubynsky] Series: pedahohika i psykholohiia. 2020. Issue 61. s. 75-78.

Translation of the Title, Abstract and References to the Author's Language

УДК 37.013

Вишківська В., Шикиринська О., Малінка О., Лобачук I. Теоретикометодологічні аспекти використання діалогу 3 метою організації продуктивної взаємодії суб'єктів освітнього процесу

У статті в історико-філософському, психологічному та педагогічному аспектах розглядається актуальна проблема вдосконалення педагогічної освіти - 
використання діалогу в здійсненні ефективної взаємодї суб'єктів освітнього процесу. Наголошується, щзо сучасна педагогічна система стикається з об'єктивними процесами демократизащії в суспільстві, з вимогами розвитку культури в умовах науково-технічного прогресу $і$ характеризується зміною дисциплінарно-примусової нормативної домінанти освіти на домінанту культурної діяльності та творчості. Аналізується діалог як форма і метод організації навчання, основу якого складають цุінності змісту та иџінності ичілі, які проявляються в проблемності, сприйнятті $i$ взаєморозумінні на міжособистісному рівні. Зауважено, щуо співучасть суб'єктів діалогу виявляе його гуманістичну сутність і надає багатобарвності, емоційності, духовності взаєминам, дарує радість відкриття людини людиною.

Акиентовано увагу на психолого-педагогічній сутності дискусії (різновид діалогу, який протікає в режимі компетентної рівності $i$ передбачає боротьбу думок учасників у ході суворо регламентованого обговорення проблеми) як найбільш ефективній у пізнавальному плані формі діалогу.

Ключові слова: діалог, навчальний діалог, педагогічна взаємодія, учасники освітнього процесу, суб’єкти навчання, дискусія

\section{Лimepamypa}

1. Абульханова-Славская К.А. Личностный аспект проблемы общения / К.А. Абульхано-ва-Славская // Проблема общения в психологии / под ред. Б.Ф. Ломова. М.: Наука, 1981. 335 с.

2. Библер В.С. Диалог культур (философия, психология, педагогика) / В.С. Библер // Первое сентября, 1998. С. 36.

3. Бом Д. Наука и духовность, необходимость изменения в культуре / Д. Бом // Человек. 1993. № 1. С. 7-17.

4. Бубер М. Я и ты / М. Бубер. М.: Высшая школа, 1993. 198 с.

5. Вишківська В.Б. Суб’єктність студентів у навчальному процесі-необхідна умова формування професійної компетентності. Науковий часопис НПУ імені М.П.Драгоманова. 2008. Вип.8 (18). С. 2-4.

6. Вишківська В., Шикиринська О. Організація процесу навчання в новій українській школі: теоретико-практичний аспект // Молодь і ринок, 2019. № 11 (178) . C. $115-119$ 
7. Кулюткин Ю.Н., Бездухов В.П. Ценностные ориентиры и когнитивные структуры в деятельности учителя. Самара: СамГПУ, 2002. 400 с.

8. Общение и диалог в практике обучения и воспитания и психологической консультации: сб. науч. тр. М.: АПН СССР, 1987. 164 с.

9. Рыданова И.И. Основы педагогики общения / И.И. Рыданова. Минск: Беларусская наука, 1998. 320 с.

10. О. В. Шикиринська, В. Б. Вишківська. Google-clasroom як засіб формування ІКТ-компетентності майбутнього вчителя початкової школи // Наукові записки Вінницького державного педагогічного університету імені Михайла Коцюбинського. Серія: педагогіка і психологія. 2020. Випуск 61. с. 75-78. 